\title{
ОБЪЕКТЫ ГРАЖДАНСКИХ ПРАВООТНОШЕНИЙ В СТРАНАХ ШОС: СРАВНИТЕЛЬНО-ПРАВОВОЙ АНАЛИЗ
}

\author{
(c) 2020 Дашин Алексей Викторович \\ доктор юридический наук, \\ профессор кафедры правового обеспечения экономической деятельности \\ Самарский государственный экономический университет, Россия, Самара \\ профессор кафедры международного частного и предпринимательского права \\ юридического факультета \\ Кубанский государственный аграрный университет им. И.Т. Трубилина, Россия, Краснодар
}

\section{(c) 2020 Шаповал Ольга Вячеславовна}

кандидат юридический наук, доцент кафедры гражданского права юридического факультета Кубанский государственный университет, Россия, Краснодар

Статья посвящена актуальным проблемам правового регулирования экономических отношений межу странами, входящими в Шанхайскую организацию сотрудничества. Настоящая статья посвящена исследованию категорий объектов гражданских прав в этих странах. Особое внимание уделено проблеме соотношения правовых норм, регулирующих общественные отношения странучастниц ШОС, относящихся к различным правовым системам.

Ключевые слова: Шанхайская организация сотрудничества, правовые системы, объекты гражданских прав, финансовые инструменты, ценные бумаги.

Шанхайская организация сотрудничества создана в 2001 году. Основной целью создания этой организации первоначально было укрепление взаимодействия в области защиты странучастниц от общих угроз. В качестве таких угроз выступали стремительно распространяющийся международный терроризм, религиозный экстремизм и этнический сепаратизм. Однако с течением времени ШОС становится площадкой для обсуждения и согласования вопросов, касающихся экономического сотрудничества, вопросов туризма, культуры, медицинского взаимодействия.

В ШОС в качестве постоянных членов входят такие страны, как Таджикистан, Узбекистан, Кыргызская республика, Казахстан, Китайская народная республика, Индия, Пакистан и Российская Федерация.

Правовые системы Китая, Индии и Пакистана обладают значительной спецификой по сравнению с Российской Федерацией и странами постсоветского пространства, которые сохранили общность с российской правовой структурой.

Наиболее емкую и точную характеристику правовой системе Китайской народной республики дал Лафитский В.И. «Правовая система КНР представляет собой уникальное правовое явление, включающее в себя характерные черты права стран социалистической системы, конфуцианские ценности, нормы традиционного (древнекитайского) права, а также принципы и нормы современного международного права. В своем развитии она прошла несколько основных этапов, каждый из которых характеризуется своими особенностями и характерными для соответствующего периода ее развития принимаемыми актами правотворчества» [1].

Правовые системы Индии и Пакистана вообще входят в англо-саксонскую правовую семью и значительная часть нормативной базы заимствована именно из английского права. Она разрознена, датируется серединой двадцатого и даже девятнадцатого века, в некоторых регионах преобладают нормы религиозного (индуистского или мусульманского) права.

Ни Индия, ни Пакистан, ни КНР не имеют единого кодифицированного акта, регулирующего гражданские правоотношения. В связи с вышесказанным, полагаем, что анализу законодательства этих стран-участниц ШОС мы посвятим отдельное исследование, а пока перейдем к сравнительной характеристике гражданского законодательства стран постсоветского пространства.

В более ранних работах нами были рассмотрены структуры гражданских кодексов Таджи- 
кистана, Узбекистана, Казахстана и Кыргызской республики, правовое положение и классификация юридических лиц, а также отдельно - некоммерческих организаций. Настоящая статья посвящена исследованию категорий объектов гражданских прав в этих странах.

Российский Гражданский кодекс является наиболее обширным и подробным правовым актом, представляющим наиболее широкий перечень объектов. Согласно ст. 128 ГК РФ «К объектам гражданских прав относятся вещи (включая наличные деньги и документарные ценные бумаги), иное имущество, в том числе имущественные права (включая безналичные денежные средства, бездокументарные ценные бумаги, цифровые права); результаты работ и оказание услуг; охраняемые результаты интеллектуальной деятельности и приравненные к ним средства индивидуализации (интеллектуальная собственность); нематериальные блага» [2].

Последними изменениями законодательства в перечень объектов гражданских прав были включены цифровые права, которые представляют собой обязательственные и иные права, содержание и условия осуществления которых определяются в соответствии с правилами информационной системы, отвечающей установленным законом признакам. Осуществление, распоряжение, в том числе передача, залог, обременение цифрового права другими способами или ограничение распоряжения цифровым правом возможны только в информационной системе без обращения к третьему лицу. Данное положение требует дальнейшей расшифровки и уточнений, которые будут внесены позднее. Пока, к сожалению, отсутствует как перечень таких прав, так и критерии отнесения к ним.

Необходимо подчеркнуть, что таких новелл ни один из рассматриваемых кодексов ни содержит.

В соответствии со ст. 115 ГК Казахстана «Объектами гражданских прав могут быть имущественные и личные неимущественные блага, и права. К имущественным благам и правам (имуществу) относятся: вещи, деньги, в том числе иностранная валюта, финансовые инструменты, работы, услуги, объективированные результаты творческой интеллектуальной деятельности, фирменные наименования, товарные знаки и иные средства индивидуализации изделий, имущественные права и другое имущество» [3].
Статья 22 ГК Кыргызской республики гласит: «К объектам гражданских прав относятся вещи, включая деньги и ценные бумаги, иное имущество, в том числе имущественные права; работы и услуги; охраняемые информация, результаты интеллектуальной деятельности и приравненные к ним средства индивидуализации (интеллектуальная собственность), а также другие материальные и нематериальные блага» [4].

Согласно ст. 140 Гражданского кодекса Таджикистана: «Объектами гражданских прав могут быть имущественные и личные неимущественные блага, и права. К имущественным благам и правам (имуществу) относятся: вещи, деньги, в том числе иностранная валюта, ценные бумаги, работы, услуги, информация, действия результаты творческой интеллектуальной деятельности, фирменные наименования, товарные знаки и иные средства индивидуализации изделия, имущественные права и другое имущество» [5].

Гражданский кодекс Узбекистана содержит ст. 81, согласно которой «К объектам гражданских прав относятся вещи, в том числе деньги и ценные бумаги, другие предметы, имущество, включая имущественные права, работы и услуги, изобретения, промышленные образцы, произведения науки, литературы, искусства и иные результаты интеллектуальной деятельности, а также личные неимущественные права и другие материальные и нематериальные блага» [6].

Как уже говорилось, ГК РФ предлагает наиболее подробный перечень объектов, в частности, он выделяет наличные и безналичные денежные средства, документарные и бездокументарные ценные бумаги, уточняет, что объектами выступают результаты работ и оказание услуг.

Гражданский кодекс Казахстана, в целом, повторяет российский перечень объектов, однако выделяет иностранную валюту и, единственный вводит в него финансовые инструменты, содержание которых раскрывается в последующих статьях. Им посвящен отдельный параграф 1-1, в котором финансовые инструменты в статье 128-1 определяются как «деньги, ценные бумаги, включая производные ценные бумаги, производные финансовые инструменты и другие финансовые инструменты, в результате операций с которыми одновременно возникают финансовый актив у одной организации и финансовое обязательство или долевой инструмент - у другой» [3].

Следующая статья 128-2 дает понятие про- 
изводных финансовых инструментов «Производный финансовый инструмент - договор, стоимость которого зависит от величины (включая колебание величины) базового актива договора, предусматривающий осуществление расчета по данному договору в будущем» [3].

$\mathrm{K}$ производным финансовым инструментам относятся опционы, фьючерсы, форварды, свопы и другие производные финансовые инструменты, отвечающие данным признакам, в том числе представляющие собой комбинацию вышеперечисленных производных финансовых инструментов».

В целом, внесение в ГК данных положений исключительно финансового характера представляется, на наш взгляд, весьма спорным, с точки зрения целесообразности.

Следует обратить внимание также на то, что в кодексах Кыргызской республики и Таджикистана в перечне объектов упоминается информация в качестве самостоятельного объекта. Затем дается расшифровка понятия охраняемой информации в виде служебной и коммерческой информации.

Кодексы Казахстана и Узбекистана не содержат указания на информацию в общем перечне, однако содержат статьи также о служебной и коммерческой тайне. Тексты указанных статей практически идентичны.

В российском ГК информация в качестве самостоятельного объекта не отражена, что, по нашему мнению, является существенным упущением законодателя. И, хотя отдельные виды охраняемой информации регулируются нормативными актами, следует не только внести ее в перечень объектов, но и дать понятие и указать виды.

ГК Кыргызской республики, в целом, содержит общий перечень объектов, не внедряя в него иных, кроме тех, которые есть в РФ и не вводит подробное их описание.

Таджикский гражданский кодекс в качестве самостоятельного объекта указывает иностранную валюту, также в остальном повторяя положения ГК РФ.

Однако, обращает на себя внимание статья 154 ГК Таджикистана, которая указывает, что «Действия (бездействия) в предусмотренных законом случаях могут быть самостоятельным объектом гражданских прав и обязанностей».

Понятие действий (бездействий) и их классификацию, однако, ГК не раскрывает.
ГК Узбекистана выделяет материальные блага и нематериальные блага в самостоятельные главы. Сам перечень объектов гражданских прав не содержит никаких новых или необычных объектов, однако упоминает после вещей и ценных бумаг некие «другие предметы», затем имущество. Можно сделать вывод, что эти другие предметы не относятся к имуществу.

Также в самом перечне подробно расшифрованы объекты интеллектуальной собственности: изобретения, промышленные образцы, произведения науки, литературы, искусства и иные результаты интеллектуальной деятельности.

Обратимся также к классификации вещей, предлагаемой кодексами. Российский ГК В первую очередь определяет понятие обротоспособности вещей, содержит деление вещей на движимые и недвижимые, делимые и неделимые, сложные, выделяет главную вещь и принадлежность, плоды, доходы и продукцию, животных, деньги и валютные ценности как особые виды вещей.

ГК Казахстана имеет такую же классификацию вещей, добавляя, однако, служебную и коммерческую тайну и здесь же раскрывает понятие интеллектуальной собственности. Таджикский ГК содержит аналогичную классификацию, но добавляет к ним еще действия, которые мы уже упоминали и приводит характеристику деления вещей на индивидуально-определённые и вещи, определяемые родовыми признаками. Также рассматривает в качестве самостоятельного объекта служебную и коммерческую тайну и охраняемые результаты интеллектуальной деятельности.

Гражданский кодекс республики Кыргызстан приводит традиционную классификацию и также, следуя за Таджикским ГК выделяет индивидуально-определённые и вещи, определяемые родовыми признаками и определяет понятие потребляемых движимых вещей. А вот Узбекский ГК выносит классификацию в отдельную статью 86, согласно которой, вещи как объект гражданских прав подразделяются на: индивидуально-определенные и определенные родовыми признаками; делимые и неделимые; потребляемые и непотребляемые; главные вещи и принадлежности; сложные вещи. Расшифровывая понятие указанных вещей в тексе закона.

Обратим внимание на понятие недвижимых вещей и их виды в рассматриваемых кодексах.

В Российской Федерации ст. 130 ГК опреде- 
ляет, что, к недвижимым вещам (недвижимое имущество, недвижимость) относятся земельные участки, участки недр и все, что прочно связано с землей, то есть объекты, перемещение которых без несоразмерного ущерба их назначению невозможно, в том числе здания, сооружения, объекты незавершенного строительства. К недвижимым вещам относятся также подлежащие государственной регистрации воздушные и морские суда, суда внутреннего плавания. Законом к недвижимым вещам может быть отнесено и иное имущество. К недвижимым вещам относятся жилые и нежилые помещения, а также предназначенные для размещения транспортных средств части зданий или сооружений (машиноместа), если границы таких помещений, частей зданий или сооружений описаны в установленном законодательством о государственном кадастровом учете порядке.

Указанное определение содержит наиболее широкий перечень объектов недвижимого имущества по сравнению в другими исследуемыми кодексами.

В частности, кодексы Таджикистана, Узбекистана, Казахстана и Кыргызской республики не содержат таких объектов недвижимости как единый недвижимый комплекс и машино-место.
В целом, все кодексы практически повторяют определение недвижимости, делая акцент на связанности с землей находящихся на ней объектов. Однако, все кодексы, помимо ГК РФ содержат в перечне объектов недвижимости многолетние насаждения, леса, которые были исключены их категории недвижимости в нашей стране. Данное положение вызвало значительные практические проблемы. Обратим свое внимание на то, как распределены права на плоды, доходы и продукции между собственником и лицом, использующим имущество. Кодексы Таджикистана, Кыргызской республики и Казахстана оставляют право на плоды, продукцию и доходы лицу, использующему имущество, а Российской федерации и Узбекистана определяют, что данные права принадлежат собственнику имущества.

В статье представлена только часть проведенного исследования, которое мы планируем продолжить в дальнейшем. Следует подчеркнуть, что, несмотря на некоторые различия, все-таки, в большей своей части гражданское законодательство исследуемых стран является схожим, что позволяет нам более успешно строить экономическое и правовое сотрудничество.

\section{Библиографический список}

1. Сравнительное правоведение: национальные правовые системы / В.Ю. Артемов, Н.М. Бевеликова, Р.Г. Газизова и др.; под ред. В.И. Лафитского. М.: ИЗиСП, КОНТРАКТ, 2013. Т. 3: Правовые системы Азии. 704 с.

2. Гражданский кодекс Российской Федерации (часть первая) от 30.11.1994 № 51-Ф3 (ред. от 18.03.2019 г. N34Ф3) (с изм. и доп., вступ. в силу с 01.10.2019) //»Российская газета», № 238-239, 08.12.1994.

3. Гражданский Кодекс Республики Казахстан (принят Верховным Советом Республики Казахстан 27 декабря 1994 года (с изменениями и дополнениями по состоянию на 01.07.2017 г.). [Электронный ресурс]. Режим доступа: http://online.zakon.kz/document/?doc_\#pos=1;-107 (дата обращения: 30.11 .2019 г.).

4. Гражданский кодекс Кыргызской Республики от 8 мая 1996 года № 15 (Часть I) (с изменениями и дополнениями по состоянию на 02.08.2017 г.). [Электронный ресурс]. Режим доступа: http://online.zakon. kz/ Document/?doc_id=30212538 (дата обращения: 30.11 .2019 г.).

5. Гражданский кодекс Республики Таджикистан от 30 июня 1999 года (Часть первая) (с изменениями и дополнениями по состоянию на 23.07.2016 г.). [Электронный ресурс]. Режим доступа: http://online. zakon.kz/ Document/?doc_id=30447927 (дата обращения: 30.11 .2019 г.)

6. Гражданский Кодекс Республики Узбекистан (Часть первая) (утверждена Законом Республики Узбекистан от 21 декабря 1995 года № 163-I) (с изменениями и дополнениями по состоянию на 14.09.2017 г.). [Электронный ресурс].- Режим доступа: http://online. zakon. kz/Document/?doc_id=30421270 (дата обращения: 30.11.2019 г.). 